\title{
Prognostic value of serum lactate levels in patients undergoing urgent heart transplant: a subanalysis of the ASIS-TC spanish multicenter study
}

Valor pronóstico de la concentración sérica de lactato de los receptores de trasplante cardiaco urgente: subanálisis del estudio multicéntrico español ASIS-TC

David Couto-Mallón, ${ }^{\text {ab }}$ Francisco González-Vílchez, ${ }^{\mathrm{c}}$ Luis Almenar-Bonet, ${ }^{\mathrm{d}}$ Beatriz

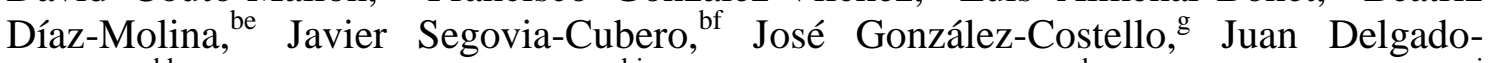
Jiménez, ${ }^{\text {bh }}$ María A. Castel-Lavilla, ${ }^{\text {bi }}$ María G. Crespo-Leiro, ${ }^{\text {ab }}$ Diego Rangel-Sousa, ${ }^{j}$ Manuel Martínez-Sellés, ${ }^{\text {bk }}$ Gregorio Rábago-Juan-Aracil, ${ }^{1}$ Luis De-la-Fuente-Galán, ${ }^{\text {m }}$ Teresa Blasco-Peiró, ${ }^{\mathrm{n}}$ Daniela Hervás-Sotomayor, ${ }^{\circ}$ Iris P. Garrido-Bravo, ${ }^{\mathrm{p}}$ Sonia Mirabet-Pérez, ${ }^{\mathrm{q}}$ Javier Muñiz, ${ }^{\text {br }}$ Eduardo Barge-Caballero ${ }^{\mathrm{ab}}$

${ }^{a}$ Servicio de Cardiología, Complejo Hospitalario Universitario A Coruña (CHUAC), Instituto de Investigación Biomédica de A Coruña (INIBIC), A Coruña, Spain

${ }^{b}$ Centro de Investigación Biomédica en Red de Enfermedades Cardiovasculares (CIBERCV), Instituto de Salud Carlos III, Madrid, Spain

${ }^{c}$ Servicio de Cardiología, Hospital Universitario Marqués de Valdecilla, Santander, Cantabria, Spain

${ }^{d}$ Servicio de Cardiología, Hospital Universitario y Politécnico La Fe, Valencia, Spain

${ }^{e}$ Servicio de Cardiología, Hospital Universitario Central de Asturias, Oviedo, Asturias, Spain

${ }^{f}$ Servicio de Cardiología, Hospital Universitario Puerta de Hierro, Majadahonda, Madrid, Spain

${ }^{g}$ Servicio de Cardiología, Hospital Universitario de Bellvitge, L'Hospitalet de Llobregat, Barcelona, Spain

${ }^{h}$ Servicio de Cardiología, Hospital Universitario 12 de Octubre, Madrid, Spain

${ }^{i}$ Servicio de Cardiología, Hospital Clínic i Provincial, Barcelona, Spain

${ }^{j}$ Servicio de Cardiología, Hospital Universitario Virgen del Rocío, Sevilla, Spain

${ }^{k}$ Servicio de Cardiología, Hospital General Universitario Gregorio Marañón, Universidad Complutense, Universidad Europea, Madrid, Spain

${ }^{l}$ Servicio de Cirugía Cardiaca, Clínica Universidad de Navarra, Pamplona, Navarra, Spain

${ }^{m}$ Servicio de Cardiología, Hospital Clínico Universitario, Valladolid, Spain

${ }^{n}$ Servicio de Cardiología, Hospital Universitario Miguel Servet, Zaragoza, Spain

${ }^{o}$ Servicio de Cirugía Cardiovascular, Hospital Universitario Reina Sofía, Córdoba, Spain

${ }^{p}$ Servicio de Cardiología, Hospital Universitario Virgen de la Arrixaca, El Palmar, Murcia, Spain

${ }^{q}$ Servicio de Cardiología, Hospital de la Santa Creu i Sant Pau, Barcelona, Spain

${ }^{r}$ Instituto Universitario de Ciencias de la Salud, Universidad de A Coruña, Instituto de Investigación Biomédica de A

Coruña (INIBIC), A Coruña, Spain 


\begin{abstract}
Introduction and objectives. To study the prognostic value of serum lactate in patients under temporary preoperative mechanical circulatory support who underwent urgent heart transplant.

Methods. We conducted a subanalysis of a Spanish multicenter registry recording data on patients under temporary mechanical circulatory support listed for highly urgent heart transplant from 2010 to 2015. Participants selected for the present study were those who received a transplant and who had known preoperative serum lactate levels. The main study outcome was 1-year survival after transplant.

Results. A total of 177 heart transplant recipients were studied; preoperatively, 90 were supported on venoarterial extracorporeal membrane oxygenation, 51 on temporary left ventricular assist devices, and 36 on temporary biventricular assist devices. Preoperative hyperlactatemia $(\geq 2 \mathrm{mmol} / \mathrm{L})$ was present in $44(25 \%)$ patients. On multivariable analysis, pretransplant serum lactate was identified as an independent predictor of 1-year posttransplant survival (adjusted HR per $0.1 \mathrm{mmol} / \mathrm{L}, 1.02 ; 95 \% \mathrm{CI}, 1.01-1.03 ; P=.007$ ). One-year posttransplant survival was $53.1 \%$ (95\% CI, 45.3-60.9) in patients with preoperative hyperlactatemia and 75.6\% (95\% CI, 71.8-79.4) in those without preoperative hyperlactatemia (adjusted HR, 1.94; 95\%CI, 1.04-3.63; $P=.039$ ). Preoperative hyperlactatemia correlated with adverse outcomes in patients supported with extracorporeal membrane oxygenation, but not in patients supported on ventricular assist devices.

Conclusions. Preoperative serum lactate is a strong independent predictor of worse outcomes in patients undergoing urgent heart transplant on short-term mechanical circulatory support.
\end{abstract}

\title{
Resumen
}

Introducción y objetivos. Analizar el impacto del lactato sérico en receptores de trasplante cardiaco urgente en asistencia circulatoria mecánica de corta duración preoperatoria.

Métodos. Se realizó un subanálisis de un registro multicéntrico español basado en pacientes incluidos en «urgencia grado 0» para trasplante cardiaco con asistencia circulatoria mecánica preoperatoria de corta duración entre 2010 y 2015. Se seleccionó a los receptores de trasplante con cifras preoperatorias de lactato conocidas. El desenlace principal fue la supervivencia 1 año tras el trasplante.

Resultados. Se estudió a 177 receptores de trasplante cardiaco urgente, de los que 90 necesitaron asistencia preoperatoria con oxigenador extracorpóreo de membrana venoarterial, 51 con asistencia ventricular izquierda y 36 con asistencia biventricular. De ellos, $44(25 \%)$ presentaban hiperlactatemia antes del trasplante $(\geq 2 \mathrm{mmol} / \mathrm{l})$. En el análisis multivariable, la cifra de lactato sérico resultó predictora independiente de mortalidad tras el trasplante (cada 0,1 mmol/l, HR ajustada $=1,02 ; \mathrm{IC} 95 \%, 1,01-1,03 ; \mathrm{p}=0,007)$. La supervivencia estimada al año del trasplante cardiaco fue del 53,1\% (IC95\%, 45,3-60,9) en los pacientes con hiperlactactemia preoperatoria y el 75,6\% (IC95\%, $71,8-79,4$ ) en los pacientes sin hiperlactatemia (HR ajustada $=1,94$; IC95\%, 1,04-3,63; p = 0,039). El impacto pronóstico de la hiperlactatemia fue significativo en los pacientes asistidos con oxigenador extracorpóreo de membrana venoarterial, pero no en aquellos con dispositivos de asistencia ventricular.

Conclusiones. Los valores preoperatorios de ácido láctico son un potente factor pronóstico independiente en receptores de trasplante cardiaco urgente.

\section{Keywords}

Lactate; Heart transplant; Mechanical circulatory support;

\section{Palabras clave}

Lactato; Trasplante cardiaco; Asistencia circulatoria mecánica

\section{Abbreviations}

ECMO, extracorporeal membrane oxygenation; HT, heart transplant; MCS, mechanical circulatory support 


\section{INTRODUCTION}

In recent years, an increasing number of heart transplant (HT) recipients have received the organ on an urgent basis. Most of these patients require the use of preoperative support with mechanical circulatory support (MCS) devices. ${ }^{1}$ Under these circumstances, hemodynamic status is a strong indicator of the risk of mortality and clinical complications after HT, with poorer prognosis seen in patients in cardiogenic shock before the procedure. ${ }^{2}$

Lactic acidosis is a serious and relatively common metabolic abnormality in patients with low cardiac output caused by a tissue oxygen supply-demand imbalance secondary to tissue hypoperfusion. ${ }^{3}$ Serum lactate levels have been investigated as a marker of adverse prognosis in a wide variety of patients with acute heart disease, ${ }^{4}$ such as acute myocardial infarction, decompensated heart failure, or cardiogenic shock, as well as in patients undergoing cardiopulmonary bypass. ${ }^{5}$ In some HT recipients, lactic acidosis has been described during the immediate postoperative period, ${ }^{6}$ although the causes and clinical impact of this phenomenon are uncertain.

The aim of the present study was to analyze a potential association between preoperative serum lactate and outcome in patients on temporary MCS listed for highly urgent HT. The working hypothesis was that serum lactate may be higher in patients with worse pretransplant hemodynamic status and thus, theoretically at higher risk of posttransplant mortality, such that lactate may be used as a prognostic predictor in these individuals. To fulfill this objective, the study analyzed information from a Spanish multicenter HT registry.

\section{METHODS}

\section{Study Description}

The ASIS-TC (Use of Short-term Mechanical Circulatory Support Devices as a Bridge to Urgent Heart Transplant in Spain) study is a retrospective multicenter registry which collected data on all patients over age 18 years listed for a highly urgent first HT who were receiving support with MCS devices from 2010 to 2015 in Spain. The study did not include patients with a previous HT or listed for multiorgan transplant. The registry included all 16 Spanish hospitals with an adult HT program.

The ASIS-TC study recorded information on patients listed with the National Transplant Organization for HT as "grade 0 urgency" (assisted with venoarterial extracorporeal membrane oxygenation [ECMO] or short-term ventricular assist devices) or "grade 1 urgency" (assisted with intra-aortic balloon pump counterpulsation). For the purpose of the study, short-term ventricular assist devices were considered to include the Impella Recover (percutaneous insertion, continuous flow), Levitronix Centrimag (surgical insertion, continuous flow), Abiomed BVS5000 (surgical insertion, pulsing flow), and similar devices. The overall results of the series have been previously published. ${ }^{7}$

The registry information was obtained by an individualized, case-by-case review of all medical records for included patients. Individuals were identified for the study by approved queries of the National Transplant Organization database, with cooperation by local and autonomous community transplant coordination offices for participating hospitals.

For each patient, more than 500 variables were collected on clinical characteristics during circulatory assist and at the time of HT, as well as on the type of device implanted, complications associated with circulatory assist, waiting list times, and posttransplant complications. Several additional variables related to donor characteristics, HT surgical procedure, and long-term posttransplant survival were obtained by targeted queries of the National Heart Transplant Registry. 
The study protocol was approved by the Clinical Research Ethics Committee of Galicia and was ratified by the ethics committees at each participating site.

We describe the results of a subanalysis of the ASIS-TC registry database focused on the prognostic value of serum lactate in patients receiving an urgent HT. The individuals selected for these analyses were patients from the "grade 0 urgency" cohort who underwent HT with registry database information on pretransplant serum lactate. Patients were not included in the analyses if they died before HT or had been excluded from the urgent waiting list.

\section{Statistical Analysis}

A descriptive and comparative analysis was performed of study patients' baseline (at HT) clinical characteristics according to the presence or absence of preoperative hyperlactatemia, defined as serum lactate $\geq 2 \mathrm{mmol} / \mathrm{L}$ at the last determination during the pretransplant waiting period. This is the most commonly accepted cutoff point in the medical literature to define abnormal serum lactate levels. ${ }^{4}$

Quantitative variables are expressed as mean \pm standard deviation, and the proportion of affected participants was used for qualitative variables. Study group distributions for qualitative variables were compared by the chi-square test or by the Student $t$ test for continuous quantitative variables.

The primary endpoint was 1-year survival after HT. The Kaplan-Meier method was used to construct survival curves over the entire period, and survival probability between study groups was compared by the log-rank test.

To identify 1-year posttransplant mortality predictors, a Cox multivariate regression was run backwards stepwise with " $P$ out" $<.05$. The first step of this analysis included clinical variables for the donor and recipient with a proven univariate association with posttransplant risk of death with $P<.20$ (recipient age, diabetes mellitus, mechanical ventilation, renal replacement therapy, ECMO-type MCS, serum creatinine, hemoglobin, vasoactive-inotropic score, serum lactate, ischemia time). The multivariate model obtained by the backwards stepwise analysis was subsequently used to estimate the hazard ratio (HR) for 1-year posttransplant mortality in patients with preoperative hyperlactatemia $(\geq 2 \mathrm{mmol} / \mathrm{L})$ compared with patients without hyperlactatemia $(<2 \mathrm{mmol} / \mathrm{L})$. A $P$ value $<.05$ was considered significant for all hypothesis contrasts. The statistical analysis was performed using SPSS 20.

\section{RESULTS}

\section{Patients}

From January 2010 to December 2015, 291 patients were listed with the National Transplant Organization for HT with a "grade 0 urgency" priority and on a temporary MCS device at 16 Spanish sites; 230 of these patients received HT. The ASIS-TC registry database contained information on preoperative serum lactate levels for $177(77 \%)$ of these urgent HT recipients, who comprised our study population.

At the time of HT, 90 patients were on venoarterial ECMO, 64 with Levitronix Centrimag (26 biventricular and 38 left ventricular), 13 with Abiomed BVS5000 (9 biventricular and 4 left ventricular), 9 with Impella Recover (left ventricular), and 1 with biventricular Abiomed AB5000.

Serum lactate levels before urgent HT in the study population are shown in Figure 1. The mean \pm standard deviation was $1.8 \pm 1.7 \mathrm{mmol} / \mathrm{L} ; 44$ recipients $(25 \%)$ of had pretransplant hyperlactatemia, defined as $\geq 2 \mathrm{mmol} / \mathrm{L}$. 


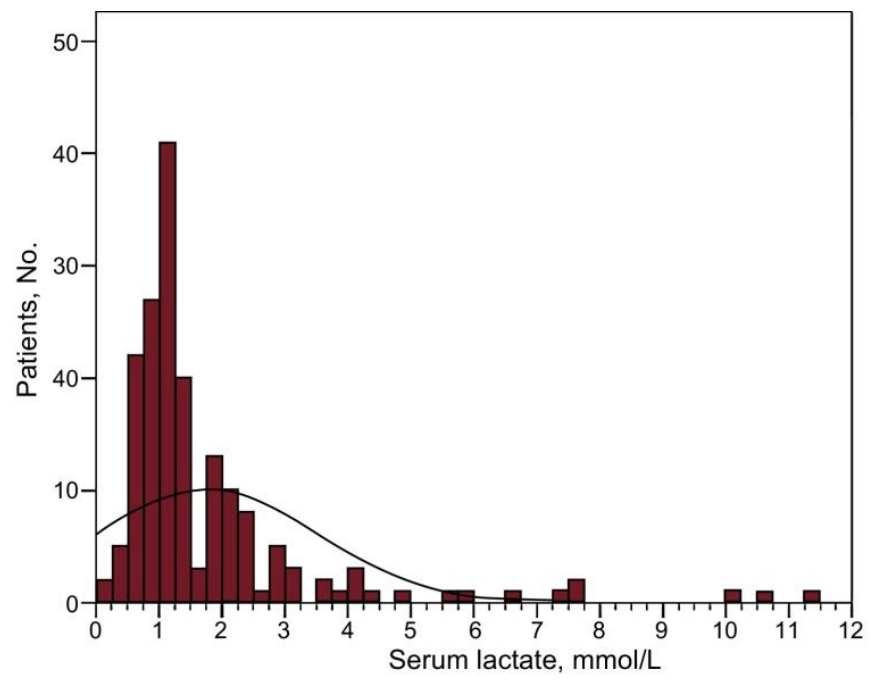

Figure 1. Distribution of pretransplant serum lactate levels in the study population.

\section{Clinical Characteristics of Patients With and Without Hyperlactatemia}

Table 1 compares the baseline clinical characteristics of all patients included in the subanalysis, based on the presence or absence of preoperative hyperlactatemia. Baseline clinical characteristics of the 177 urgent HT recipients in the cohort analyzed were similar to those of the 230 urgent HT recipients in the overall ASIS-TC cohort. 
Table 1. Comparison of Baseline Clinical Characteristics for Study Patients According to the Presence or Absence of Pretransplant Hyperlactatemia

\begin{tabular}{|c|c|c|c|}
\hline Variables & Lactate $<2 \mathrm{mmol} / \mathrm{L}(\mathrm{n}=133)$ & Lactate $\geq 2 \mathrm{mmol} / \mathrm{L}(\mathrm{n}=44)$ & $P$ \\
\hline \multicolumn{4}{|l|}{ Recipient characteristics } \\
\hline Age, $y$ & $50.9 \pm 12.2$ & $49.8 \pm 13.6$ & .604 \\
\hline Women, \% & 19 & 34 & .035 \\
\hline MCS type, \% & & & .147 \\
\hline Venoarterial ECMO & 50 & 55 & \\
\hline Left ventricular assist & 32 & 18 & \\
\hline Biventricular assist & 18 & 27 & \\
\hline MCS duration, $d$ & $14.5 \pm 12.6$ & $12.5 \pm 17.3$ & .747 \\
\hline Time on urgent waiting list, $d$ & $8.2 \pm 9.2$ & $7.1 \pm 6.3$ & .458 \\
\hline Ischemic heart disease, $\%$ & 51 & 48 & .696 \\
\hline Diabetes mellitus, \% & 24 & 20 & .623 \\
\hline History of heart surgery, $\%$ & 20 & 21 & .896 \\
\hline Cardiopulmonary arrest, $\%$ & 17 & 18 & .801 \\
\hline Active infection requiring IV therapy, $\%$ & 13 & 18 & .373 \\
\hline INTERMACS profile 1 or $2, \%$ & 74 & 80 & .493 \\
\hline Intra-aortic balloon pump counterpulsation, $\%$ & 23 & 27 & .524 \\
\hline Renal replacement therapy, $\%$ & 9 & 11 & .648 \\
\hline Invasive mechanical ventilation, $\%$ & 61 & 73 & .048 \\
\hline Vasoactive-inotropic score & $16 \pm 43$ & $48 \pm 74$ & .015 \\
\hline Creatinine, $m g / d L$ & $1.03 \pm 0.6$ & $1.29 \pm 0.8$ & .022 \\
\hline Hemoglobin, $g / d L$ & $9.2 \pm 1.1$ & $9.6 \pm 2.0$ & .216 \\
\hline Bilirubin, $m g / d L$ & $1.8 \pm 2.5$ & $1.6 \pm 1.7$ & .641 \\
\hline$G O T, I U / L$ & $97 \pm 250$ & $102 \pm 100$ & .906 \\
\hline Albumin, $g / d L$ & $2.9 \pm 0.7$ & $2.6 \pm 1$ & .247 \\
\hline$I N R$ & $1.3 \pm 0.2$ & $1.4 \pm 0.4$ & .165 \\
\hline$p H$ & $7.43 \pm 0.1$ & $7.42 \pm 0.1$ & .502 \\
\hline Lactate, $\mathrm{mmol} / \mathrm{L}$ & $1.1 \pm 0.4$ & $3.9 \pm 3.4$ & $<.001$ \\
\hline Left ventricular ejection fraction, $\%$ & $23 \pm 12$ & $22 \pm 10$ & .638 \\
\hline Cardiac index, $\mathrm{mL} / \mathrm{min} / \mathrm{m}^{2}$ & $2.3 \pm 0.6$ & $2.3 \pm 0.7$ & .989 \\
\hline Mean pulmonary pressure, $\mathrm{mmHg}$ & $29 \pm 13$ & $26 \pm 10$ & .322 \\
\hline \multicolumn{4}{|l|}{ Donor characteristics } \\
\hline Age, $y$ & $42.7 \pm 11.5$ & $43.4 \pm 13.4$ & .747 \\
\hline Women, \% & 27 & 27 & .979 \\
\hline Ischemia time, $\min$ & $215 \pm 62$ & $222 \pm 47$ & .449 \\
\hline
\end{tabular}

ECMO, extracorporeal membrane oxygenation; GOT, glutamic oxaloacetic transaminase; INTERMACS, Interagency Registry for Mechanically Assisted Circulatory Support; MCS, mechanical circulatory support.

Unless otherwise indicated, the date are expressed as mean \pm standard deviation.

There was a higher proportion of women among patients with hyperlactatemia, and the latter were more likely to be on invasive mechanical ventilation and to have higher serum creatinine and higher vasoactive-inotropic score before HT. Mean pretransplant serum lactate was $1.1 \pm 0.4 \mathrm{mmol} / \mathrm{L}$ in patients without hyperlactatemia and $3.9 \pm 3.4 \mathrm{mmol} / \mathrm{L}$ in patients with hyperlactatemia. 


\section{Posttransplant Survival}

A total of 52 (29.4\%) patients died during the first year after HT; 48 of these deaths occurred during the immediate postoperative hospitalization.

The Cox univariate analysis showed a statistically significant association between preoperative serum lactate and 1-year posttransplant risk of death (per $0.1 \mathrm{mmol} / \mathrm{L}$, crude $\mathrm{HR}=1.01$; $95 \%$ confidence interval $[95 \% \mathrm{CI}], 1.00-1.02 ; P=.040$ ). Figure 2 shows the Kaplan-Meier survival curves during this period, with stratification of the study population by preoperative serum lactate tertiles. The log-rank test showed a statistically significant linear trend for 1-year posttransplant mortality in the higher preoperative lactate tertiles $(P=.01)$.

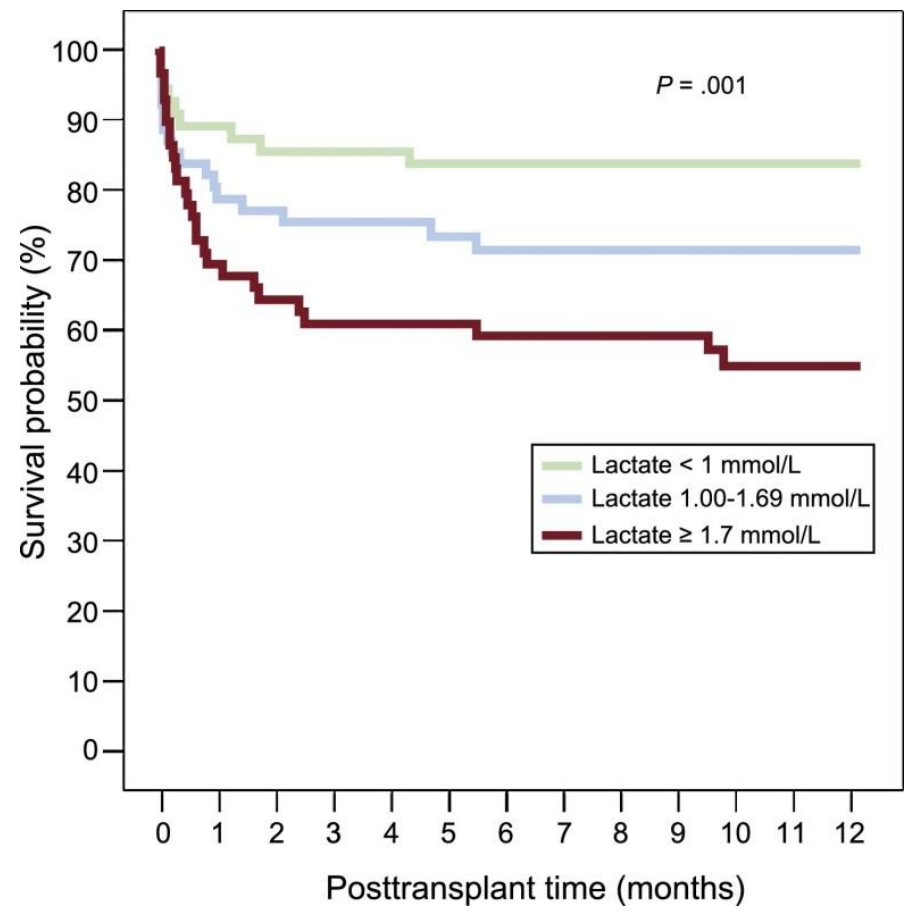

Figure 2. One-year posttransplant survival curves, stratified by preoperative serum lactate tertiles. Tertile 1: preoperative serum lactate $<1 \mathrm{mmol} / \mathrm{L}$; tertile 2 : $1.00-1.69 \mathrm{mmol} / \mathrm{L}$; tertile $3: \geq 1.7 \mathrm{mmol} / \mathrm{L}$.

In the Cox multivariate analysis, preoperative serum lactate was an independent predictor of higher 1year posttransplant risk of death (per $0.1 \mathrm{mmol} / \mathrm{L}$, adjusted $\mathrm{HR}=1.02 ; 95 \% \mathrm{CI}, 1.01-1.03 ; P=.007$ ). Other independent predictors of mortality were recipient age, ischemia time, vasoactive-inotropic score, and pretransplant venoarterial ECMO, as shown in Table 2. 
Table 2. Independent Predictors of 1-year Posttransplant Mortality: Cox Multivariate Analysis

\begin{tabular}{lll}
\hline & HR $(95 \% \mathrm{CI})$ & $P$ \\
\hline & & \\
Age, per $10 \mathrm{y}$ & $1.52(1.15-2.03)$ & .004 \\
Vasoactive-inotropic score, per 10 units & $1.05(1.01-1.10)$ & .021 \\
Ischemia time, per h & $1.80(1.26-2.57)$ & .001 \\
Venoarterial ECMO & $2.35(1.27-4.35)$ & .007 \\
Serum lactate, per $0.1 \mathrm{mmol} / \mathrm{L}$ & $1.02(1.01-1.03)$ & .007 \\
& & \\
\hline
\end{tabular}

95\%CI, 95\% confidence interval; ECMO, extracorporeal membrane oxygenation; HR, hazard ratio.

According to the Kaplan-Meier estimate, the probability of 1-year posttransplant survival was $53.1 \%$ (95\%CI, 45.3-60.9) for patients with preoperative hyperlactatemia ( $\geq 2 \mathrm{mmol} / \mathrm{L})$ and 75.6\% (95\%CI, 71.8-79.4) for patients without hyperlactatemia $(P=.011)$. The adjusted HR for 1-year posttransplant mortality in patients with preoperative hyperlactatemia $(\geq 2 \mathrm{mmol} / \mathrm{L})$ compared with patients without hyperlactatemia was $1.94(95 \% \mathrm{CI}, 1.04-3.63 ; P=.039)$.

\section{Causes of Death}

Table 3 lists the causes of posttransplant death based on the presence or absence of preoperative hyperlactatemia $(\geq 2 \mathrm{mmol} / \mathrm{L})$. In patients with hyperlactatemia, bacterial infections $(\mathrm{n}=7[35 \%])$, primary graft failure $(n=5[25 \%])$, and postoperative multiorgan failure $(n=4[20 \%])$ were the most common causes of mortality, accounting for $80 \%$ of all deaths. Patients without hyperlactatemia showed more variety in the causes of mortality, with the most frequent being primary graft failure $(n=10[31 \%])$.

Table 3. Causes of 1-Year Posttransplant Death in Patients With and Without Preoperative Hyperlactatemia

\begin{tabular}{lll}
\hline & $\begin{array}{l}\text { Lactate }<2 \mathrm{mmol} / \mathrm{L} \\
(\mathrm{n}=32 / 133), \mathrm{no} .\end{array}$ & $\begin{array}{l}\text { Lactate } \geq 2 \mathrm{mmol} / \mathrm{L} \\
(\mathrm{n}=20 / 44), \mathrm{no} .\end{array}$ \\
\hline Primary graft failure & 10 & 5 \\
Postoperative multiorgan failure & 4 & 4 \\
Surgical hemorrhage & 2 & 1 \\
Technical complication & 1 & 0 \\
Bacterial infection & 3 & 7 \\
Cytomegalovirus infection & 1 & 0 \\
Aspergillus infection & 1 & 0 \\
Ischemic stroke & 2 & 1 \\
Hemorrhagic stroke & 3 & 0 \\
Postanoxic encephalopathy & 2 & 0 \\
Hyperacute rejection & 1 & 0 \\
Acute rejection & 1 & 1 \\
Neoplasm & 0 & 1 \\
Sudden cardiac death & 1 & 0 \\
& & \\
\hline
\end{tabular}




\section{Types of Mechanical Circulatory Support}

Figure 3 contains the 1-year posttransplant Kaplan-Meier survival curves for patients with and without preoperative hyperlactatemia, according to the type of MCS used at the time of HT.
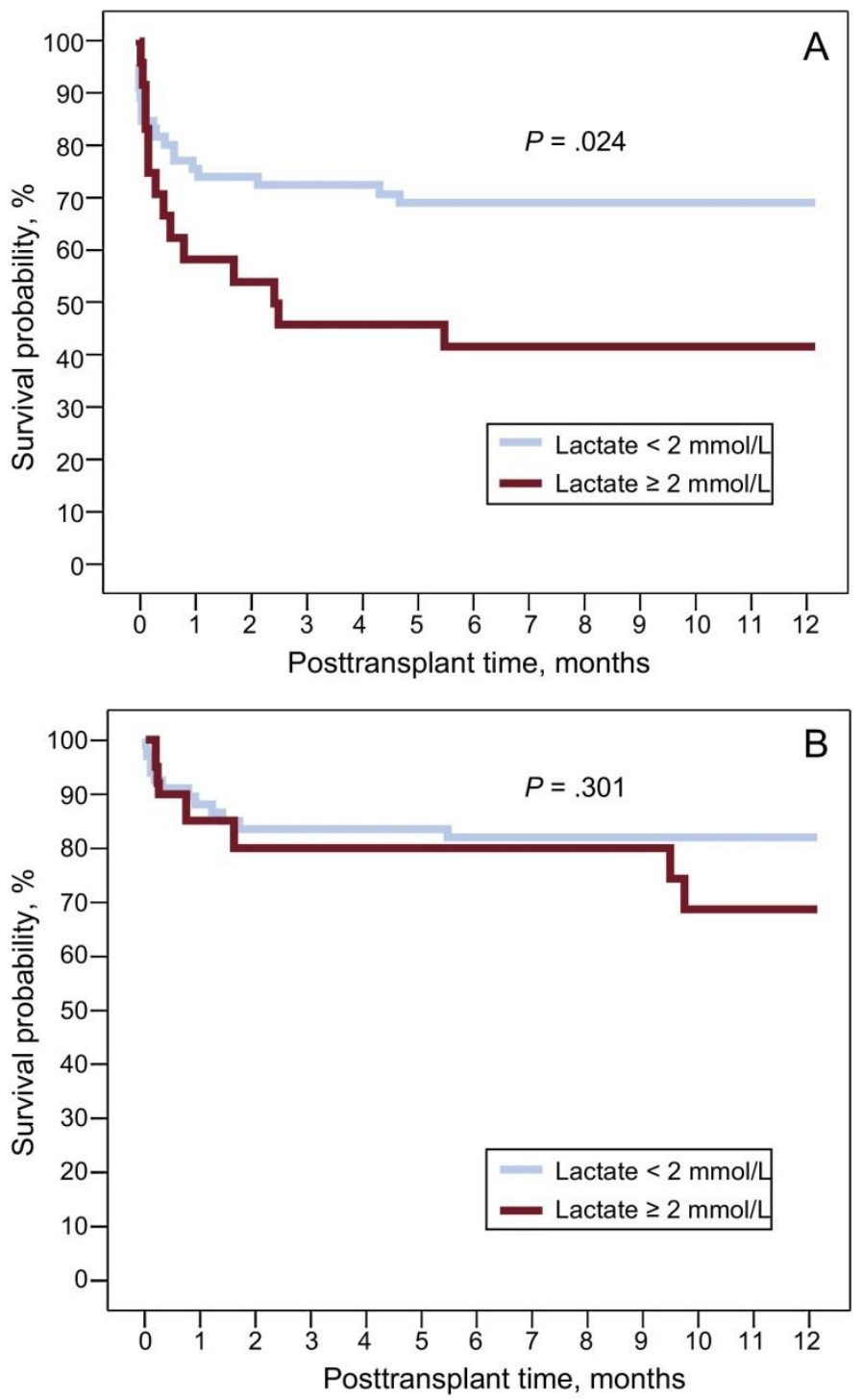

Figure 3. One-year posttransplant survival curves according to the presence or absence of hyperlactatemia (serum lactate $\geq 2 \mathrm{mmol} / \mathrm{L}$ ) prior to surgery. A, patients with venoarterial extracorporeal membrane oxygenation. $\mathrm{B}$, patients with temporary ventricular assist devices.

In the subgroup of patients supported with venoarterial ECMO, preoperative hyperlactatemia was associated with a statistically significant increase in 1-year posttransplant mortality $(P=.024)$; however, no significant differences were observed in posttransplant mortality between patients with and without preoperative hyperlactatemia in the subgroup of recipients on short-term ventricular assist devices $(P=$ $.301)$. 


\section{DISCUSSION}

We present a subanalysis of the ASIS-TC multicenter registry database, which collects clinical information on all patients listed for urgent HT on temporary MCS devices at 16 Spanish sites between 2010 and 2015. The main result of this study is the evidence that preoperative serum lactate is of significant prognostic impact in this population. In fact, after multivariate adjustment, the risk of early mortality after urgent HT was almost 2 -fold for recipients with preoperative hyperlactatemia $(\geq 2$ $\mathrm{mmol} / \mathrm{L}$ ) compared with the rest of the study population.

Because serum lactate can be measured quickly and simply, its clinical value has been investigated widely in the critical medicine setting. ${ }^{8}$ The earliest observations were made by Weil and Afifi, ${ }^{3}$ and several later studies have reported that lactic acidosis is a diagnostic component and a marker of adverse prognosis in patients with acute heart disease and circulatory shock ${ }^{4}$ as well as in patients with severe sepsis, ${ }^{9}$ multiple injuries, and critical neurologic disease.

In the context of cardiogenic shock, lactic acidosis is mainly the result of tissue hypoperfusion, which leads to a net oxygen supply-demand imbalance in target organs. However, other pathophysiologic mechanisms contribute to this phenomenon. Additionally, high circulating catecholamines are present in shock situations - either as a physiologic response to low cardiac output or as a consequence of the treatment itself-which favors an increase in sarcolemmal $\mathrm{Na} / \mathrm{K}$ ATPase activity, thus leading to increased glycogenolysis and aerobic glycolysis, raising serum lactate. ${ }^{10}$ Patients with decompensation of pre-existing advanced heart failure seem to be particularly vulnerable in this regard, due to a tendency to move rapidly from aerobic to anaerobic metabolism. ${ }^{11}$ Last, patients with cardiogenic shock, particularly if they require invasive ventilatory or circulatory assist, are prone to septic complications that can cause significant lactate accumulation even in the absence of significantly impaired tissue perfusion. ${ }^{9}$

Preoperative hyperlactatemia ( $\geq 2 \mathrm{mmol} / \mathrm{L}$ ) was a common laboratory finding in this population, as it affected 1 of every 4 recipients of urgent HT. Due to its design, the study only included lactate levels nearest to the time of HT; in fact, hyperlactatemia would probably have been more common if the study had included levels obtained during the acute phase of cardiogenic shock prior to MCS use. Furthermore, moderately elevated lactate among patients with hyperlactatemia (mean, $3.9 \mathrm{mmol} / \mathrm{L}$ ) indicates that there may be some selection bias in the sample analyzed, ie, the health care team may have excluded some patients with refractory cardiogenic shock and severe metabolic acidosis from the HT waiting list, believing that it might be ineffectual.

Apart from these considerations, the study shows a direct association between serum lactate before urgent HT and postoperative mortality. The practical importance of this result is obvious, particularly because this clinical scenario accounts for almost half the HT procedures currently performed in Spain ${ }^{1}$ and because this high-risk context is precisely where clinical tools are most needed to stratify postsurgery prognosis and to identify situations where a successful outcome is unlikely. As expected, most posttransplant HT deaths in this cohort occurred during the immediate postoperative period, and the most common causes of mortality were primary graft failure, postoperative multiorgan failure, and sepsis.

The statistical association observed is even more interesting due to its biological plausibility and its independence of other adverse prognostic factors in the context of urgent HT that might correlate with lactate levels, such as vasoactive-inotropic score, ${ }^{12}$ a recently validated formula to standardize the vasoactive support doses received by a critically-ill patient. Moreover, the association between preoperative lactate levels and posttransplant mortality HT shows a dose-response relationship, such that patients with borderline values considered normal-to-high, eg, patients in the second tertile of the sample distribution (1.00-1.69 $\mathrm{mmol} / \mathrm{L})$, were at higher risk than patients with strictly normal values $(<1$ $\mathrm{mmol} / \mathrm{L}$ ). The ability of preoperative lactate to predict prognosis in urgent HT recipients was even stronger in individuals with a higher risk profile, such as those supported by venoarterial ECMO.7, 13 
The elevated postoperative mortality observed with pretransplant hyperlactatemia (nearly $50 \%$ at 1 year of follow-up) indicates the need to reconsider the therapeutic approach in these patients. Persistent lactic acidosis despite adequate MCS should lead the health care team to question the suitability of listing the patient for urgent HT at that time or accepting an organ if the patient is already listed. In patients in an early phase of cardiogenic shock, it might be sufficient to defer HT listing several days to allow hemodynamic status to normalize and metabolic abnormalities and target organ function to be corrected, thus permitting HT to be undertaken with greater expectations of success. In patients with a longer course, the development of progressive lactic acidosis in the absence of other underlying causes (eg, sepsis) might indicate poor clinical progress and multiorgan failure which, if persistent, would contraindicate HT due to the unlikelihood of a successful outcome.

\section{Limitations}

This study has several limitations. The first is related to the observational and retrospective nature of the registry, which may have led to the selection, information, or confusion biases inherent to this type of study. As stated in the Methods section, 53 recipients of urgent HT were excluded from this subanalysis due to a lack of information on their preoperative lactate levels; however, the clinical characteristics and posttransplant mortality of patients included in the subanalysis were generally consistent with those of the registry as a whole.

In view of the retrospective nature of the registry, it was not possible to define a priori the same specific time point for serum lactate determinations in all patients; moreover, because this was a multicenter study without a single core laboratory, the test results may be subject to local variations. There was also no information on postoperative serum lactate trends after HT. Last, serum lactate $\geq 2$ $\mathrm{mmol} / \mathrm{L}$ was arbitrarily selected as a cutoff to define hyperlactatemia due to widespread acceptance in the medical literature. However, the use of alternative cutoff points was not explored in this analysis to avoid problems of multiple comparisons, which might have led to different conclusions from those obtained.

\section{CONCLUSIONS}

This study supports the independent prognostic value of preoperative serum lactate levels of patients on temporary MCS devices who undergo urgent HT. In recipients with preoperative hyperlactatemia $(\geq 2$ $\mathrm{mmol} / \mathrm{L}$ ), mortality is high during the early postoperative stage after urgent $\mathrm{HT}$-nearly $50 \%$ at 1 year of follow-up_, suggesting the need to reconsider the therapeutic approach taken in this complex clinical scenario.

According to the results obtained, persistent serum lactate elevation in a candidate for urgent HT in MCS should be considered a warning sign for the transplant team. Hyperlactatemia is a sensitive but nonspecific marker of an adverse clinical course. This may be because MCS is insufficient in time or intensity, because irreversible multiorgan failure is already established, or because there are other intercurrent processes, such as undetected sepsis. For some patients, the correct decision in this scenario may be to wait for greater hemodynamic stability, for recovery of target organ function, or for treatment of an intercurrent process before listing them for urgent HT. In other patients, the most appropriate option may to limit therapeutic efforts due to poor prognosis and give the organ to another recipient more likely to survive posttransplant.

\section{FUNDING}

The ASIS-TC registry was funded by a health research grant from the Fundación Mutua Madrileña (10th edition, 2014). Moreover, some authors are affiliated with the CIBERCV (Biomedical Research Center in the Cardiovascular Diseases Network) at the Carlos III Health Institute, as listed in the manuscript authors. 


\section{CONFLICTS OF INTEREST}

E. Barge-Caballero has received an academic grant from Abbott Vascular unrelated to this research project.

\section{Acknowledgments}

The authors would like to thank the National Transplant Organization for its support and assistance during the various stages of this research project.

The authors would also like to thank the following for their cooperation with this study: Gonzalo Barge-Caballero, María J. Paniagua Martín, Raquel López Villela, Ignacio Sánchez Lázaro, Manuel Gómez Bueno, Luis Alonso Pulpón, Francisco Hernández Pérez, Josebe Goirigolzarri Artaza, Inés Ponz de Antonio, Adriana Rodríguez Chaverri, Laura Morán Fernández, José Luis Lambert Rodríguez, Carles Díez López, Nicolás Manito Lorite, Álvaro Andrés Herrera Escandón, Marisa Sanz Julve, Ana Portolés Ocampo, Eulalia Roig Mingell, Vicens Brossa Loidi, Laura López López, Montserrat Lorente, Rebeca Manrique Antón, Ignacio Muñoz Carvajal, Javier Arias Dachary, Azahara Fernández Carbonell, José María Turégano Cisneros, Laura Inga Távara, José Joaquín Domínguez del Castillo, María Teresa Conejero Jurado, María Isabel Pernía Oreña, José Antonio Vázquez de Prada, Elisabet Fernández Fernández, and Francisco José Pastor Pérez.

\section{REFERENCES}

1. González-Vílchez F, Gómez-Bueno M, Almenar-Bonet L, et al. Spanish Heart Transplant Registry. 28th Official Report of the Spanish Society of Cardiology Working Group on Heart Failure (19842016). Rev Esp Cardiol. 2017;70:1098-1109.

2. Barge-Caballero E, Segovia-Cubero J, Almenar-Bonet L, et al. PreoperativeINTER-MACS profiles determine postoperative outcomes in critically ill patients under-going emergency heart transplantation: analysis of the Spanish National Heart Transplant Registry. Circ Heart Fail. 2013;6:763-772.

3. Weil MH, Afifi AA. Experimental and clinical studies on lactate and pyruvate as indicators of the severity of acute circulatory failure (shock). Circulation. 1970;41:989-1001.

4. Attanà $\mathrm{P}$, Lazzeri C, Picariello $\mathrm{C}$, Dini CS, Gensini GF, Valente S. Lactate and lactate clearance in acute cardiac care patients. Eur Heart J Acute Cardiovasc Care. 2012;1:115-121.

5. Demers P, Elkouri S, Martineau R, Couturier A, Cartier R. Outcome with high blood lactate levels during cardiopulmonary bypass in adult cardiac operation. Ann Thorac Surg. 2000;70:2082-2086.

6. Mohacsi P, Pedrazzinia G, Tanner H, Tschanz HU, Hullin R, Carrel T. Lactic acidosis following heart transplantation: a common phenomenon? Eur J Heart Fail. 2002;4:175-179.

7. Barge-Caballero E, Almenar-Bonet L, Gonzalez-Vilchez F, et al. Clinical outcomes of temporary mechanical circulatory support as a direct bridge to heart transplantation: a nationwide Spanish registry. Eur J Heart Fail. 2018;20:178-186.

8. Levy B. Lactate and shock state: the metabolic view. Curr Opin Crit Care. 2006;12:315-321.

9. Levy B, Gibot S, Franck P, Cravoisy A, Bollaert PE. Relation between muscle $\mathrm{Na}^{+} \mathrm{K}^{+} \mathrm{ATPase}$ activity and raised lactate concentrations in septic shock: a prospective study. Lancet. 2005;365:871-875.

10. McCarter FD, James JH, Luchette FA, et al. Adrenergic blockade reduces skeletal muscle glycolysis and $\mathrm{Na}^{+}, \mathrm{K}^{+}$ATPase activity during hemorrhage. J Surg Res. 2001;99:235-244.

11. Myers J, Froehlicher VF. Hemodynamic determinants of exercise capacity in chronic heart failure. Ann Intern Med. 1991;115:377-386.

12. Barge-Caballero E, Segovia-Cubero J, González-Vílchez F, et al. Evaluation of the preoperative vasoactive-inotropic score as a predictor of post-operative outcomes in patients undergoing heart transplantation. Int J Cardiol. 2015;185:192-194.

13. Li CL, Wang H, Jia M, Ma N, Meng X, Hou XT. The early dynamic behavior of lactate is linked to mortality in postcardiotomy patients with extracorporeal membrane oxygenation support: a retrospective observational study. J Thorac Cardiovasc Surg. 2015;149:1445-1450. 